\title{
Heat Meets DNA: DNA Damage and Repair
}

\author{
YOSUKE NAKAGAWA $^{1}$, ATSUHISA KAJIHARA ${ }^{1}$, TADAAKI KIRITA ${ }^{1}$, \\ EIICHIRO MORI ${ }^{2 *}$
}

\author{
${ }^{1}$ Department of Oral and Maxillofacial Surgery, Nara Medical University, Shijo-cho 840, Kashihara, Nara \\ 634-8521, Japan \\ ${ }^{2}$ Department of Future Basic Medicine, Nara Medical University, Shijo-cho 840, Kashihara, Nara 634-8521, \\ Japan
}

\begin{abstract}
Hyperthermia is generally used in combination with chemo and radiation therapy in the treatment of various cancers. Thus far, most studies have focused on the additive effects of heat shock. However, it is also critical to understand the solitary effect of heat shock stress on mammalian cells. DNA double-strand breaks (DSBs) are known to be generated by ionizing radiation and a variety of DNA modifying reagents. As shown by neutral comet assays and $\gamma \mathrm{H} 2 \mathrm{AX}$ (phosphorylated histone $\mathrm{H} 2 \mathrm{AX}$ at serine 139) focus formation, heat shock also induces DSBs. While existing literature suggests that heat shock leads to cell death through the induction of DSBs, the pathway involved in repairing heat-induced damage remains to be elucidated. In the current review, we examined the history of hyperthermia, from the discovery of DSBs after heat shock, to our recent finding regarding the homologous recombination repair pathway after heat shock.
\end{abstract}

Key Words: DNA damage, DNA double-strand break (DSB), $\gamma \mathrm{H} 2 \mathrm{AX}$, DNA repair, homologous recombination (HR)

\section{Introduction}

Heat shock is one of the many environmental stressors that we deal with in our daily life; the temperature around us is constantly changing each day and night, throughout the year. As a result of biological evolution, cells, from bacterium to mammal, have developed distinct conserved cellular response pathways, including DNA damage recognition and repair, cell survival, and death and cell cycle checkpoints. Cells utilize these mechanisms to facilitate cellular homeostasis against multiple cellular stresses. Thus, an understanding of how cells respond to heat shock will allow us to gain better insight into the biological evolutionary processes against various environmental stresses.

\section{Discovery of heat-induced DNA double-strand breaks}

DNA double-strand breaks (DSBs) are by far, the most lethal DNA damage that can occur and, if left unrepaired, cause total cell death or carcinogenesis ${ }^{1)}$. For many years, the detection of DSBs remained a

Received 13 October, 2017, Accepted 8 May, 2018: *Corresponding author: Tel, +81-744-22-3051; Fax, +81-744-25-7657;

email, emori@naramed-u.ac.jp

doi: 10.3191 /thermalmed.34.15

2018 Japanese Society for Thermal Medicine 
challenge. It was not until 1998 when Rogakou et al. reported a method involving the use of phosphorylated form of histone $\mathrm{H} 2 \mathrm{AX}$ at serine $139(\gamma \mathrm{H} 2 \mathrm{AX})$ to detect single DSBs (one $\gamma \mathrm{H} 2 \mathrm{AX}$ focus represents one DSB) ${ }^{2}$ that a new era in the DNA repair field began, and many DNA damaging reagents/methods were subsequently found to induce $\mathrm{DSBs}^{3)}$.

Heat was previously not known to induce DSBs, but recent reports suggest that heat may induce DNA damage in mammalian cells ${ }^{4}$. For example, Ohnishi and colleagues used a neutral comet assay and a $\gamma \mathrm{H} 2 \mathrm{AX}$ assay with the human lung carcinoma cell line H1299 to report that heat shock did indeed induce DSBs $^{5}$. They observed a linear increase with time in the number of $\gamma \mathrm{H} 2 \mathrm{AX}$ foci when cells were heated at $41.5^{\circ} \mathrm{C}$ to $45.5^{\circ} \mathrm{C}$. They also subsequently found heat-induced $\gamma \mathrm{H} 2 \mathrm{AX}$ focus formation in other human cell lines and mammalian cell lines ${ }^{6}$. Heat-induced $\gamma \mathrm{H} 2 \mathrm{AX}$ reached a peak at approximately $2 \mathrm{~h}$. For ionizing radiation (IR), H2AX phosphorylation reached a peak approximately 15-30 min after DSB induction. This discovery was replicated by several other groups using other human and mammalian cell lines ${ }^{7,8)}$. In addition, Takahashi et al. found a nice correlation between heat-induced $\gamma \mathrm{H} 2 \mathrm{AX}$ focus number and cellular heat sensitivity ${ }^{5}$. When cells were heated at $41.5^{\circ} \mathrm{C}$ to $45.5^{\circ} \mathrm{C}$, they observed a linear increase with time in the number of $\gamma \mathrm{H} 2 \mathrm{AX}$ foci. According to the Arrhenius plot analysis, thermal activation energies above and below the inflection point of $42.5^{\circ} \mathrm{C}$ were almost the same for cell killing and focus formation. These results suggest that the number of $\gamma \mathrm{H} 2 \mathrm{AX}$ foci is correlated with the temperature dependence of cell killing.

\section{DNA damage response after heat shock}

A number of DNA damage responses are triggered upon the exposure of cells to heat. Meiotic Recombination 11 (MRE11), RAD50 and Nibrin (NBN or NBS1) form a complex called MRN. This complex recognizes DSBs and activates ataxia-telangiectasia mutated (ATM) kinase to amplify the signal of DSBs by phosphorylating hundreds of its substrates ${ }^{9}$. DNA-dependent protein kinase (DNA-PK) is another major kinase in DNA damage response. It consists of DNA-binding subunits (Ku: Ku70 and Ku80) and the catalytic subunit (DNA-PKcs). A third kinase to regulate DNA damage response together with ATM and DNA-PK is the ataxia telangiectasia and Rad3-related (ATR) protein ${ }^{10)}$. H2AX is phosphorylated mainly by ATM $^{11)}$, but it can be a substrate of DNA-PK and ATR as well ${ }^{12}$. Heat shock has been found to induce H2AX phosphorylation by ATM ${ }^{13)}$. A study revealed that the inhibition of ATM enhances the heat sensitivity of cells ${ }^{14)}$, and heat shock activates ATM and ATR, promoting the phosphorylation of their substrates Chk2 and Chk ${ }^{15,16)}$. Taken together, evidence from various studies demonstrates that heat shock activates multiple DNA damage response pathways to protect cellular, especially nuclear, components.

DNA damage recognition factors, such as MRE11, RAD50, NBS1, were known to translocate from the nucleus to the cytoplasm after heat shock (Fig. 1A), and in fact, this was thought to be one of the reasons why DNA damage is not repaired efficiently when IR and heat treatment are used together ${ }^{17}$. This finding accounts for why heat-induced DSBs are different from those induced by IR. In one of our studies, we observed that the heat shock-induced cytoplasmic translocation of the MRN complex is followed by nuclear re-translocation ${ }^{18)}$. The MRN complex re-localized in nuclei forms foci, and they become more distinct and larger in foci size at later time points (approximately 8 to 12 hours after heat shock) in our experimental conditions. These larger foci may represent unrepaired DSBs or DSBs that are difficult to repair. This suggests that delayed recruitment of DSB recognition factors may lead to persistent DSBs, which in turn result 
in inefficient DSB repair and more cell death.

Many importins are rendered dysfunctional after heat shock, with Hikeshi as the only exception to this ${ }^{18)}$. Hikeshi is a novel importin that can selectively import multiple factors required for cellular response to heat shock. Molecular trafficking after heat shock may be an important biological aspect, and further investigations into the reasons of translocation of DNA repair factors (e.g., MRN complex) to the cytoplasm may help us better understand the effect of heat shock on the DNA repair system.

A

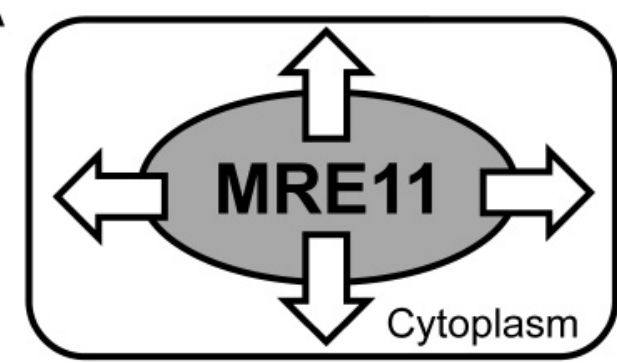

Heat-induced translocation

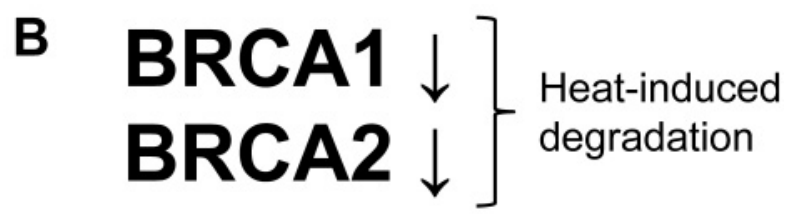

Fig. 1. Effects of heat shock on mammalian cells. (A) Heat shock induces cytoplasmic translocation of nuclear MRE11. This translocation is believed to be one of the reasons why DNA damage is not efficiently repaired when ionizing radiation and heat treatment are used together. (B) Heat shock induces degradation of BRCA1/2. Among the DSB repair factors, BRCA1/2 are degraded but not other factors.

\section{Heat-induced DSBs are repaired by the homologous recombination pathway}

Two pathways are known to be involved in DSB repair in mammalian cells: non-homologous endjoining (NHEJ) repair and homologous recombination (HR) repair ${ }^{1)}$. NHEJ repair is active throughout all cell cycle phases, and mediated by DNA-dependent protein kinase [DNA-PK: DNA-PKcs (catalytic subunit) and $\mathrm{Ku} 70 / 80]^{20)}$. HR repair takes advantage of either the homologous chromosomes or the sister chromatid to correctly re-join broken DNA ends during late $S$ and $\mathrm{G}_{2}$ phases, but not during $\mathrm{G}_{1}$ phase ${ }^{21)}$. Proteins involved in the HR repair pathway in vertebrate cells include breast cancer susceptibility gene 2 (BRCA2), RAD52, RAD54, and RAD51 paralogs such as X-ray repair cross-complementing protein 2/3 (XRCC2/3), RAD51B, RAD51C, and RAD51D22). RAD51 activity is regulated by BRCA2, which is an upstream protein to RAD5123). RAD51 is a polymorphic gene and one of the central proteins in HR repair pathway. RAD51 has two distinct roles in: (i) the restart of stalled replication forks, and (ii) HR repair of collapsed replication forks $^{24)}$.

Heat shock affects the stability/activity of several DNA repair factors: Ku70/80 (inactivation/ aggregation) ${ }^{25,26)}$, DNA-PK (reduced kinase activity) ${ }^{27-29)}$, MRE11/RAD50/NBS1 (cytoplasmic translocation) ${ }^{16,17,30)}$, BRCA1 (degradation) ${ }^{31)}$, BRCA2 (degradation) ${ }^{32)}$, (Fig. 1B), and other HR factors ${ }^{33)}$. 
The NHEJ pathway was not shown to be involved in radio-sensitization by heat ${ }^{33)}$. More recently, however, another group reported that targeting DNA-PKcs enhanced radio-sensitization by heat ${ }^{34}$. While the HR pathway is a potential target for thermal-radio-sensitization ${ }^{33)}$, the discrepancy in findings across the various groups may be due to the differential research materials used (e.g., cell type, species).

We recently reported that mammalian cells are capable of repairing DSBs by utilizing the HR pathway, but not NHEJ ${ }^{35)}$ (Fig. 2). This work was supported by several lines of experiments that compared the RAD51 (HR) inhibitor (B02) and the DNA-PK (NHEJ) inhibitor (NU7026) in human glioma cell lines, and RAD54 (HR) and LIG4 (NHEJ) knockout mouse embryonic fibroblasts. The enhancement ratio from blocking RAD51 with B02 in response to heat shock was approximately two-fold, while the contribution of both RAD54 and RAD51D in response to heat shock was approximately 1.3-fold. The contributions of RAD54 in response to heat shock and X-rays were approximately 1.3 and 1.8, respectively, while those of LIG4 were approximately 1.0 and 8.9, respectively. It would suggest that the LIG4 (NHEJ) plays major roles in repairing DSBs, and during cellular resistance in response to IR, regardless of the cell cycle phase; it appears to have no role in the response to heat shock throughout the cell cycle. It is important to note that the RAD54-deficient chicken B-lymphocyte cell line DT40 was more sensitive to heat shock compared with wild-type cell line ${ }^{36}$. In addition, the recombination assay with SPD8 cells (Chinese hamster cells to detect HR repair events) ${ }^{37)}$ showed that heat shock generates DNA damage, which must be repaired by the HR pathway ${ }^{35)}$.

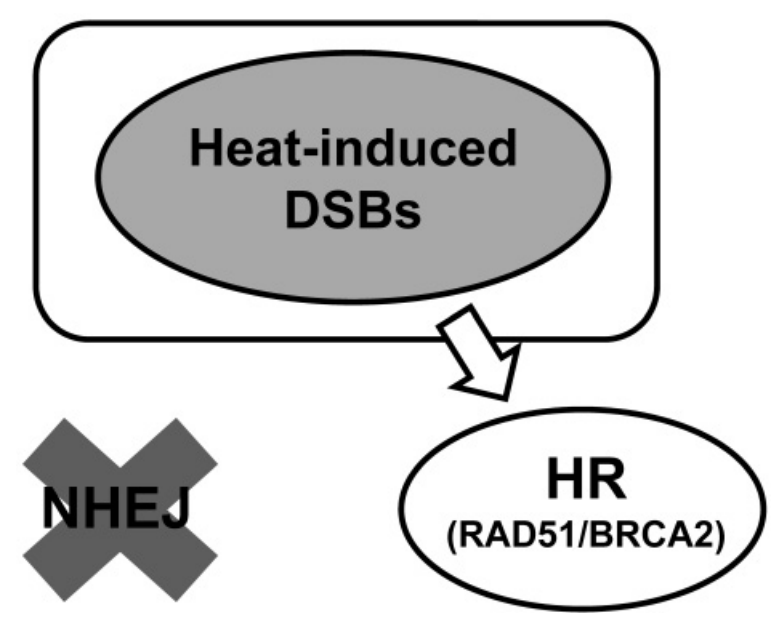

Fig. 2. Heat-induced DSBs are repaired by HR but not by NHEJ. RAD51 and BRCA2 play important roles in protecting mammalian cells from heat shock.

\section{BRCA2 as a target of heat shock}

BRCA2 is required for survival in the presence of 5-fluorouracil ${ }^{38)}$, formaldehyde ${ }^{39)}$, and DNA alkylating agents ${ }^{40)}$, and Krawczyk et al.'s study suggests that heat shock leads to the degradation of BRCA2, while PARP inhibition sensitizes cells to heat shock ${ }^{32}$. In our recent study, we demonstrated the protective role of BRCA2 in sensitivity to heat shock and DSB repair ${ }^{41)}$. Cells transfected with BRCA2-siRNA were more sensitive to heat than cells transfected with negative control siRNA. The number of apoptotic bodies increased more rapidly in BRCA2-siRNA transfected cells than in cells transfected with negative control siRNA when cells were observed at $48 \mathrm{~h}$ after a heat treatment. Our results suggest for certain that in response to heat shock, 
BRCA2 acts as an HR repair factor to repair DSBs caused by heat shock; the possibility of its other roles remain to be investigated and clarified.

Heat shock has two effects on BRCA2: (i) protein degradation ${ }^{32}$, and (ii) repairing DSBs induced by heat shock $^{41)}$. The simplest interpretation of this phenomena is that heat shock leads to degradation of BRCA2, although enough BRCA2 remains to participate in HR and repair DSBs induced by heat shock; cells with insufficient BRCA2 are not capable of repairing DSBs, hence their inability to survive. It is also possible that surviving cells were able to translate new BRCA2 with the help of HSP90, a chaperone protein that helps proteins to fold even under heat shock and known to interact with BRCA2, where the newly translated BRCA2 engages in DSB repair ${ }^{42}$. This may account for the absence of a larger difference between cellular sensitivity to heat shock, and the radiation sensitivity observed in NHEJ deficiency.

\section{Conclusion}

Mammalian cells have evolved multiple pathways to protect themselves from various environmental stressors. Heat shock has long been thought to cause little to no DNA damage, and leads to the inhibition of DNA repair machineries. However, our recent findings show that heat does induce DSBs and under heat shock conditions, cells are still capable of repairing DSBs exclusively by the HR pathway. Further investigations are required to understand the molecular biology of heat shock responses.

\section{Acknowledgement}

Most of the works presented here were done in collaboration with the late Dr. Takeo Ohnishi, who passed away recently. The authors thank Dr. Ohnishi for his direction of and support for these projects over these years, and Keren-Happuch E Fan Fen and Akiho S. Murata for their critical reading of the manuscript. This work was supported by grants from JSPS KAKENHI [17H07031 (Grant-in-Aid for Research Activity start-up) to E.M.], Takeda Science Foundation granted to E.M., Kanzawa Medical Research Foundation to E.M., The Uehara Memorial Foundation to E.M., The Nakatomi Foundation to E.M., and Konica Minolta Science and Technology Foundation to E.M.

\section{References}

1) Ohnishi T., Mori E., Takahashi A.: DNA double-strand breaks: their production, recognition, and repair in eukaryotes. Mutat Res, 669: 8-12, 2009.

2) Rogakou E.P., Pilch D.R., Orr A.H., Ivanova V.S., Bonner W.M.: DNA double-stranded breaks induce histone H2AX phosphorylation on serine 139. J Biol Chem, 273: 5858-5868, 1998.

3) Takahashi A., Ohnishi T.: Does $\gamma \mathrm{H} 2 \mathrm{AX}$ foci formation depend on the presence of DNA double strand breaks ? Cancer Lett, 229: 171-179, 2005.

4) Wang Y., Perrault A.R., Iliakis G.: Replication protein A as a potential regulator of DNA replication in cells exposed to hyperthermia. Radiat Res, 149: 284-293, 1998.

5) Takahashi A., Matsumoto H., Nagayama K., Kitano M., Hirose S., Tanaka H., Mori E., Yamakawa N., Yasumoto J., Yuki K., Ohnishi K., Ohnishi T.: Evidence for the involvement of double-strand breaks in heat-induced cell killing. Cancer Res, 64: 8839-8845, 2004.

6) Takahashi A., Mori E., Somakos G.I., Ohnishi K., Ohnishi T.: Heat induces $\gamma \mathrm{H} 2 \mathrm{AX}$ foci formation in mammalian cells. Mutat Res, 656: 88-92, 2008. 
7) Kaneko H., Igarashi K., Kataoka K., Miura M.: Heat shock induces phosphorylation of histone H2AX in mammalian cells. Biochem Biophys Res Commun, 328: 1101-1106, 2005.

8) Hunt C.R., Pandita R.K., Laszlo A., Higashikubo R., Agarwal M., Kitamura T., Gupta A., Rief N., Horikoshi N., Baskaran R., Lee J.H., Löbrich M., Paull T.T., Roti Roti J.L., Pandita T.K.: Hyperthermia activates a subset of ataxia-telangiectasia mutated effectors independent of DNA strand breaks and heat shock protein 70 status. Cancer Res, 67: 3010-3017, 2007.

9) Kobayashi J., Tauchi H., Chen B., Burma S., Tashiro S., Matsuura S., Tanimoto K., Chen D.J., Komatsu K.: Histone H2AX participates the DNA damage-induced ATM activation through interaction with NBS1. Biochem Biophys Res Commun, 380: 752-757, 2009.

10) Durocher D., Jackson S.P.: DNA-PK, ATM and ATR as sensors of DNA damage: Variations on a theme? Curr Opin Cell Biol, 13: 225-231, 2009.

11) Burma S., Chen B.P., Murphy M., Kurimasa A., Chen D.J.: ATM phosphorylates histone H2AX in response to DNA doublestrand breaks. J Biol Chem, 276: 42462-42467, 2001.

12) Tomimatsu N., Mukherjee B., Burma S.: Distinct roles of ATR and DNA-PKcs in triggering DNA damage responses in ATM-deficient cells. EMBO Rep, 10: 629-635, 2009.

13) Takahashi A., Mori E., Su X., Nakagawa Y., Okamoto N., Uemura H., Kondo N., Noda T., Toki A., Ejima Y., Chen D.J., Ohnishi K., Ohnishi T.: ATM is the predominant kinase involved in the phosphorylation of histone H2AX after heating. $\mathrm{J}$ Radiat Res, 51: 417-422, 2013.

14) Tuul M., Kitao H., Iimori M., Matsuoka K., Kiyonari S., Saeki H., Oki E., Morita M., Maehara Y.: Rad9, Rad17, TopBP1 and claspin play essential roles in heat-induced activation of ATR kinase and heat tolerance. PLoS One, 8: e55361, 2013.

15) Furusawa Y., Iizumi T., Fujiwara Y., Zhao Q.L., Tabuchi Y., Nomura T., Kondo T.: Inhibition of checkpoint kinase 1 abrogates G2/M checkpoint activation and promotes apoptosis under heat stress. Apoptosis, 17: 102-112, 2012.

16) Furusawa Y., Yamanouchi Y., Iizumi T., Zhao Q.L., Mitsuhashi Y., Morita A., Enomoto A., Tabuchi Y., Kondo T.: Checkpoint kinase 2 is dispensable for regulation of the p53 response but is required for $\mathrm{G} 2 / \mathrm{M}$ arrest and cell survival in cells with p53 defects under heat stress. Apoptosis, 22: 1225-1234, 2017.

17) Zhu W.G., Seno J.D., Beck B.D., Dynlacht J.R.: Translocation of MRE11 from the nucleus to the cytoplasm as a mechanism of radiosensitization by heat. Radiat Res, 156: 95-102, 2001.

18) Takahashi A., Mori E., Ohnishi T.: The foci of DNA double strand break-recognition proteins localize with $\gamma \mathrm{H} 2 \mathrm{AX}$ after heat treatment. J Radiat Res, 51: 91-95, 2010.

19) Kose S., Furuta M., Imamoto N.: Hikeshi, a nuclear import carrier for Hsp70s, protects cells from heat shock-induced nuclear damage. Cell, 149: 578-589, 2012.

20) Davis A.J., Chen B.P., Chen D.J.: DNA-PK: A dynamic enzyme in a versatile DSB repair pathway. DNA Repair (Amst), 17: 21-29, 2014.

21) Chapman J.R., Taylor M.R., Boulton S.J.: Playing the end game: DNA double-strand break repair pathway choice. Mol Cell, 47: 497-510, 2012.

22) Liu Y., Tarsounas M., O'regan P., West S.C.: Role of RAD51C and XRCC3 in genetic recombination and DNA repair. J Biol Chem, 282: 1973-1979, 2007.

23) Shin D.S., Pellegrini L., Daniels D.S., Yelent B., Craig L., Bates D., Yu D.S., Shivji M.K., Hitomi C., Arvai A.S., Volkmann N., Tsuruta H., Blundell T.L., Venkitaraman A.R., Tainer J.A.: Full-length archaeal Rad51 structure and mutants: mechanisms for RAD51 assembly and control by BRCA2. EMBO J, 22: 4566-4576, 2003.

24) Petermann E, Orta ML, Issaeva N, Schultz N, Helleday T. Hydroxyurea-stalled replication forks become progressively inactivated and require two different RAD51-mediated pathways for restart and repair. Mol Cell 37:492-502, 2010.

25) Burgman P., Ouyang H., Peterson S., Chen D.J., Li G.C.: Heat inactivation of Ku autoantigen: possible role in hyperthermic radiosensitization. Cancer Res, 57: 2847-2850, 1997.

26) Beck B.D., Dynlacht J.R.: Heat-induced aggregation of XRCC5 (Ku80) in nontolerant and thermotolerant cells. Radiat Res, 
156: 767-774, 2001.

27) Ihara M., Suwa A., Komatsu K., Shimasaki T., Okaichi K., Hendrickson E.A., Okumura Y.: Heat sensitivity of doublestranded DNA-dependent protein kinase (DNA-PK) activity. Int J Radiat Biol, 75: 253-258, 1999.

28) Woudstra E.C., Konings A.W., Jeggo P.A., Kampinga H.H.: Role of DNA-PK subunits in radiosensitization by hyperthermia. Radiat Res, 152: 214-218, 1999.

29) Ihara M., Takeshita S., Okaichi K., Okumura Y., Ohnishi T.: Heat exposure enhances radiosensitivity by depressing DNA-PK kinase activity during double strand break repair. Int J Hyperthermia, 30: 102-109, 2014.

30) Seno J.D., Dynlacht J.R.: Intracellular redistribution and modification of proteins of the Mre11/Rad50/Nbs1 DNA repair complex following irradiation and heat-shock. J Cell Physiol, 199: 157-170, 2004.

31) Xian Ma Y., Fan S., Xiong J., Yuan R.Q., Meng Q., Gao M., Goldberg I.D., Fuqua S.A., Pestell R.G., Rosen E.M.: Role of BRCA1 in heat shock response. Oncogene, 22: 10-27, 2003.

32) Krawczyk P.M., Eppink B., Essers J., Stap J., Rodermond H., Odijk H., Zelensky A., van Bree C., Stalpers L.J., Buist M.R., Soullié T., Rens J., Verhagen H.J., O’Connor M.J., Franken N.A., Ten Hagen T.L., Kanaar R., Aten J.A.: Mild hyperthermia inhibits homologous recombination, induces BRCA2 degradation, and sensitizes cancer cells to poly (ADP-ribose) polymerase-1 inhibition. Proc Natl Acad Sci USA, 108: 9851-9856, 2011.

33) Genet S.C., Fujii Y., Maeda J., Kaneko M., Genet M.D., Miyagawa K., Kato T.A.: Hyperthermia inhibits homologous recombination repair and sensitizes cells to ionizing radiation in a time- and temperature-dependent manner. J Cell Physiol, 228: 1473-1481, 2013.

34) van Oorschot B., Granata G., Di Franco S., Ten Cate R., Rodermond H.M., Todaro M., Medema J.P., Franken N.A.: Targeting DNA double strand break repair with hyperthermia and DNA-PKcs inhibition to enhance the effect of radiation treatment. Oncotarget, 7: 65504-65513, 2016.

35) Takahashi A., Mori E., Nakagawa Y., Kajihara A., Kirita T., Pittman D.L., Hasegawa M., Ohnishi T.: Homologous recombination preferentially repairs heat-induced DNA double-strand breaks in mammalian cells. Int J Hyperthermia, 33 : 336-342, 2017.

36) Yin HL., Suzuki Y., Matsumoto Y., Tomita M., Furusawa Y., Enomoto A., Morita A., Aoki M., Yatagai F., Suzuki T., Hosoi Y., Ohtomo K., Suzuki N.: Radiosensitization by hyperthermia in the chicken B-lymphocyte cell line DT40 and its derivatives lacking nonhomologous end joining and/or homologous recombination pathways of DNA double-strand break repair. Radiat Res, 162: 433-441, 2004.

37) Helleday T., Arnaudeau C., Jenssen D.: A partial hprt gene duplication generated by non-homologous recombination in V79 Chinese hamster cells is eliminated by homologous recombination. J Mol Biol, 279: 687-694, 1998.

38) Nakagawa Y., Kajihara A., Takahashi A., Kondo N., Mori E., Kirita T., Ohnishi T.: The BRCA2 gene is a potential molecular target during 5-fluorouracil therapy in human oral cancer cells. Oncol Rep, 31: 2001-2006, 2014.

39) Noda T., Takahashi A., Kondo N., Mori E., Okamoto N., Nakagawa Y., Ohnishi K., Zdzienicka M.Z., Thompson L.H., Helleday T., Asada H., Ohnishi T.: Repair pathways independent of the Fanconi anemia nuclear core complex play a predominant role in mitigating formaldehyde-induced DNA damage. Biochem Biophys Res Commun, 404: 206-210, 2011.

40) Kondo N., Takahashi A., Mori E., Noda T., Zdzienicka M.Z., Thompson L.H., Helleday T., Suzuki M., Kinashi Y., Masunaga S., Ono K., Hasegawa M., Ohnishi T.: FANCD1/BRCA2 plays predominant role in the repair of DNA damage induced by ACNU or TMZ. PLoS One, 6: e19659, 2011.

41) Nakagawa Y., Kajihara A., Takahashi A., Murata A.S., Matsubayashi M., Ito S.S., Ota I., Nakagawa T., Hasegawa M., Kirita T., Ohnishi T., Mori E.: BRCA2 protects mammalian cells from heat shock. Int J Hyperthermia, in press. doi: 10.1080/02656736.2017.1370558.

42) Pennisi R, Ascenzi P, di Masi A. Hsp90: a new player in DNA repair? Biomlecules, 5: 2589-2618, 2015. 


\title{
Abstract in Japanese
}

\section{温熱と DNA との出会い: DNA 損傷と修復}

\author{
仲川洋介 $^{1}$. 梶原淳 ${ }^{1} \cdot$ 桐田忠昭 ${ }^{1} \cdot$ 森 英一朗 ${ }^{2}$ \\ 1奈良県立医科大学・ 口腔外科学講座 \\ 2奈良県立医科大学・ 未来基礎医学教室
}

要旨: 温熱療法は, 化学療法や放射線療法と組み合わせて, 様々ながんの治療に用いられる. 多 くの研究は, 温熱による増感作用に着目している。一方, 温熱単独処理による哺乳動物細胞への影響研 究も非常に重要である.DNA二本鎖切断は, DNA 修飾剤や放射線により引き起こされる。温熱によっ ても引き起こされることが中性コメットアッセイや $\gamma \mathrm{H} 2 \mathrm{AX}$ のフォーカス形成により確認されている. 温熱はDNA二本鎖切断を引き起こすことで細胞死を導くと考えられているが，温熱が引き起こす DNA 損傷にどのような修復経路が関与するのか明らかではない. 本総説では, 温熱処理後に DNA二 本鎖切断が形成されることの発見から，近年の相同組換え経路を用いた修復に関する研究内容を含めて 紹介する。

Thermal Med, 34[2]: 15-22, 2018. 